\title{
Buyan Tamblingan Agro Tourism Ethical Planning in Forest Conservation Border Areas
}

\author{
I Gusti Bagus Rai Utama ${ }^{1}$, Christimulia Purnama Trimurti ${ }^{2}$ \\ \{raiutama@undhirabali.ac.id ${ }^{1 *}$, christimulia@gmail.com ${ }^{2}$ \} \\ Hotel Management Program, Dhyana Pura University ${ }^{1}$, \\ Management Study Program, Dhyana Pura University ${ }^{2}$
}

\begin{abstract}
Tamblingan area is supported by natural beauty and the authenticity of its forest conservation and the peculiarities of people's gardens in the form of indigenous flowers and citrus gardens. That garden is professionally managed with the development of agrotourism models. The best prospective alternative to diversify the agricultural sector can increase community welfare. Agrotourism development in the Tamblingan lake tourism park area will has a good impact if several planning ethical values are applied, while the ethics are: (1) Nature namely natural areas so that the hazards need to be maintained by the concept of sustainable tourism is realized for next generations. (2) The uniqueness of this area with cool temperatures of all times, with unique natural scenery must be maintained and preserved rather than exploited. (3) Scarcity, which is a conservation forest that stretches along a tourist park, is something that is considered rare in this era, and the concept of conservation or nature conservation must continue to be carried out so that this area will continue to attract all time. (4) Optimization of Land Use: farmers can prosper if they do a combination of products with the development of agrotourism which can be of double value by combine the agricultural sector and the tourism sector. (5) Labor Involvement, which is a large part of the community around the living areas of farming livelihoods, and development of agrotourism can involve village communities..
\end{abstract}

Keywords: agricultural sector, agrotourism, conservation forest, uniqueness, naturalness.

\section{Introduction}

Buyan and Tamblingan Nature Tourism Park administratively located in the Sukasada District, Banjar District, Buleleng Regency and Baturiti District, Tabanan Regency. This region, based on the Decree of the Minister of Forestry No: 144 / Kpts-II / 1996 dated April 4, 1996, was designated as the Batukahu Forest Area (RTK.4) located in Dati District II Tabanan and Dati District II Buleleng Province Dati .I Bali, covering an area of 1,336.50 Ha as Lake Buyan-Lake Tamblingan Nature Tourism Park, where there is an $8 \mathrm{Ha}$ enclave. The extensive revision of the area in accordance with the Decree of the Head of the Regional Office of the Ministry of Forestry No: 140 / Kwl-5/1997 dated January 22, 1997, then the area of Lake Buyan and Lake Tamblingan Nature Park became 1,703 Ha. The Buyan-Lake and Tamblingan Lake Nature Park area borders: (1) North Side: Wanagiri Village, Lemukih Village. (2) East Side: Protected Forest, District of Peken, Pancasari Village. (3) South Side: Batunya Village, Candikuning Village. (4) West side: Tamblingan Hamlet, Munduk and Gesing Villages[1]. 
Lake Buyan and Lake Tamblingan Nature Tourism Park area varies from flat $(0-3 \%)$, Slope (3-8\%), Sloping (8-5\%), rather steep (15-30\%), steep (30-45\%) and steep (>45\%) with altitude from sea level ranging from $1210 \mathrm{~m}$ asl to $1350 \mathrm{~m}$ asl. The northern and eastern parts of the Lake Buyan and Lake Tamblingan Nature Tourism Park area are all very steep slopes. The southern part of this forest boundary, especially those between the two lakes, is also very steep. The steep and rather steep slope is between Lake Buyan and Lake Tamblingan. Some of the eastern and southern parts of Lake Buyan and Lake Tamblingan have sloping to flat slopes. In accordance with the Schmidt and Ferguson classifications included in climate type A with an average rainfall of $2000-2800 \mathrm{~mm} /$ year and average rainy days / year 155.6 days, wet months 4-10 and dry months $0-5$, with the air temperature ranges from $11.5^{\circ}-24^{\circ} \mathrm{C}$. Type of forest in Buyan Lake Nature Park and Tamblingan Lake including the type of mountain tropical rain forest which is characterized by high rainfall. The condition of the area is always wet with a diversity of plant species that are relatively height. Forest vegetation type in Lake Buyan and Lake Tamblingan Nature Tourism Park is included in the type of mountain tropical rainforest with conditions that are generally intact and natural. In addition to natural forests that are still intact there are also jackfruit reforestation plants (Artocarpus sp) in 1986/87 located on the shores of Lake Buyan and Lake Tamblingan, plantations of Damar species (Agathis alba), Rasamala (Altingea excelsa) and Cempaka (Mechelia champaka) and shrubs thicket which is the class of Murbai reforestation.

Based on the results of the inventory of flora and fauna in 1988, it shows that the species are lateng (Laportea sp), dominating at the tree level, followed by species of bunut (ficus indica), timber (Eugenia jambaloides) and Sambu (Vernonia arbaca). Homalanthus giganteus), stone wood (Eugenia jambaloides) and Lempeni (Ardisisa humulis). At the seedling level the types that dominate are Lateng, Lempeni and Udu species (Lithea velirtinia), while for understorey species consist of ferns, clumps, chillies, areca nut forest and others.

Based on observations in the field of fauna species found in the area of Lake Buyan-Lake Tamblingan Nature Tourism Park consisting of types of Forest Chicken (Gallus sp), Cerucuk (Pycnonotus goievier), Gray Apes (Macaca fascicularis) and other types, especially the Aves. In an indirect encounter can be found through impurities, traces and sounds such as the type of Deluk (Melogale orientalis), Sri Scissors (Dicrurus renifer) and Scratch (Estrilda amandava) The diversity of species in this area is relatively less than the Batukahu Nature Reserve, this caused by the lack of available food sources.

Attraction: the existence of two quite large lakes surrounded by still beautiful forests and charming steep cliffs, making this area has an attractive natural panorama. In locations that have a certain height can release fatigue to enjoy the view of this lake. In some locations on the edge of the lake there are also several temples that are built between large and dense trees, so that they can add to the potential that is not only beautiful but unique and distinctive.

Nature Tourism Activities: Activities that can be carried out include: water tourism, fishing, camping, crossing, exploring, jungle tracking, scientific tourism / tourism. Facilities and Facilities: This Nature Tourism Park already has 2 campground units with MCK facilities, shelter, guard posts, canoes, and guide staff. Location Achievement: To reach the location, you can use public transportation (mini bus) from Ubung Terminal, Denpasar to go to Singaraja / Pancasari route down in Pancasari Village with a distance of $57 \mathrm{Km}$ and travel time of \pm 1.5 hours. From Singaraja city -Pancasari - Bedugul as far as $32 \mathrm{Km}$ with a travel time of 40 minutes.

Stakeholders in tourism development if grouped consist of four groups, namely (1) Central Government and regions as regulators, mediators, and dynamists and motivators. (2) Communities in areas or objects or tourist parks as hosts. (3) Private (business actors) both 
tourism facilities and services, and the last is (4) Tourists, who will enjoy the entire product presented by other stakeholders. An area can be developed into Agro Tourism by considering the following things: (1) Consideration of Scarcity, (2) Consideration of Nature of Nature. (3) Uniqueness Considerations. (4) Consideration of Labor Involvement. (5) Considerations for Optimizing Land Use. (6) Consideration of Justice. (7) Equity Considerations [2].

\section{Method}

This study uses a mixed methods approach by research design with collects, analyzes, and combines both quantitative and qualitative data in order to understand a research problem. Descriptive statistical analysis techniques are used to describe a set of data visually, which can be done in two parts, namely numerical, text and graphic descriptions[3].Qualitative analysis techniques is also used to carry out several explorations and confirm some stakeholders' answers regarding the ethical aspects of agro-tourism planning at borders conservation forest areas[4]

\section{Result and Discussion}

\subsection{Ethics of Agro-tourism Development Munduk Tamblingan}

Scarcity Considerations: If we take a walk around the Tamblingan Lake Tourism Park, we will be treated to a garden of thousand flowers (148 ha), interspersed with citrus plants ( 25 ha), coffee plantation (403 ha), garlic garden (11,230 ha) and other types of vegetables such as chili (10 ha), carrots and so on. The consideration of scarcity is the presence of a thousand flowers that are not owned by other regions[5].Consideration of Nature of Nature: This area is an area that quite natural because. It is still new and beautiful, and it may still be reorganized or redesigned to become an attractive agrotourism area. In addition to being located adjacent to the well-known tourist area, Bedugul, infrastructure is relatively easy to reach both by domestic and also foreign tourists. To reach the location, we can use public transportation (mini bus) from Ubung Terminal, Denpasar to the Singaraja route stop at Pancasari Village with a distance of $57 \mathrm{Km}$ and travel time of \pm 1.5 hours. From Singaraja city to Bedugul as far as $32 \mathrm{Km}$ with a travel time of 40 minutes[6].Uniqueness Considerations: This area also has a quite prominent uniqueness, with a stretch of flower gardens and many temples (33 temples) that have the potential to become a religious area[7].Consideration of Labor Involvement: It is noted that the composition of the population of the village of Munduk is quite varied when viewed from its livelihood: 51 (fifty one) people as Civil Servants, 12 ABRI Persons, 353 Private Employees, 15 traders, 1,684 farmers, 233 Builders, 655 farm workers 14 retirees, 11 fishermen. By looking at the livelihood configurations of the Munduk villagers as above, it is hoped that if farmers can develop life agro-tourism, the majority can be raised more prosperously [8].

Considerations for Optimizing Land Use: The area of plantation and paddy fields that are only recorded 294 hectares is quite apprehensive for the use narrow of land. The alternative is the development of agro-tourism based on certain unique plants such as a thousand flowers with a combination of oranges, orchid gardens or other possible plants can be sold to tourists directly[6].Fairness Considerations: The opinion sharing system from the management of the Tamblingan lake tourism park is currently configured to be: $45 \%$ for the regional government, $45 \%$ for the traditional village of Munduk and $10 \%$ for KSDA (Natural Resources 
Conservation). If agrotourism can be developed, of course community-based agrotourism will be able to directly improve the welfare of the community, either in the form of purchasing agricultural products directly by tourists or by the Farmer Welfare Center which must be formed later so that the concept of equality can be shared fairly[9].Equity Consideration: Agro-tourism development will be expected to be able to transform the economy of the community as a whole, both farmers or villages, investors or investors, regulators (Pemda, BKSDA, Adat villages and Diparsenibud) by coordinating in planning in detail from the existing inputs[2].

\subsection{Munduk Tamblingan Agrotourism Arrangement}

Agro tourism is essentially an activity that integrates agricultural systems and tourism systems so as to form attractive tourism objects. To be able to develop an area into a tourism area there are five elements that must be fulfilled as below: (1) Attractions: things that attract the attention of tourists: The area around the wiasata park in Tamblingan lake actually has many interesting places that can be relied on as attractions such as: Conservation Forests, lakes, temples, thousand flower plantations, of course if it will be developed into agro tourism both seeds and planting methods must be rearranged so that it will be more attractive for tourists to buy them. (2) Facilities: facilities needed may be the addition of public facilities, telecommunications, hotels and restaurants to potential attraction market centers. in part, there are only additions and quality improvements. Infrastructure: Infrastructure: Infrastructure referred to in the form of irrigation systems, communication networks, health facilities, transportation terminals, electricity and energy sources, sewerage systems, roads and security systems. (3) Transportation: transportation services for public transportation, bus-terminal, passenger security system, travel information system, labor, tariff certainty, city / tourist map. Hospitality: Hospitality or willingness to receive guests. (4) The hospitality of the people will be a reflection of the success of a good tourism system. To be able to make the community friendly and ready to accept the arrival of tourists, the local community must absolutely be involved in the tourism development system in the Tamblingan area so that community welfare increases and the community economy revolves on its own. (5) Capital: If the five elements have been fulfilled, now our concern is how to obtain capital for its development. The development of the Munduk agro-tourism area is expected not to adopt of capitalist South Bali-based tourism development, the community is only a spectator in their own country. Public facilities may be built by the government, presuming small businesses in the form of community business centers that might be cultivated by the community should the community be fully involved as a whole tourism actor. Development is not only directed at pursuing income targets but how many small communities can be involved in the system developed[10].

\section{Conclusion}

The uniqueness of the Tamblingan area which is supported by natural beauty and the authenticity of its forest conservation and the peculiarities of people's gardens in the form of a thousand flowers and orange orchards that have just developed if professionally managed with the development of agrotourism models will be the best prospective alternative to diversifying the agricultural sector as well as the tourism sector in improving community welfare. Agro- 
tourism development in the Tamblingan lake tourism park area will have a good impact if several planning ethical values are applied, while the ethics are:(1) Nature: Lake Tamblingan Tourism Area is an area that still natural so that its slowness needs to be maintained with the concept of sustainable tourism materializes for generations to come. (2) Uniqueness: The uniqueness of this region with its cool temperatures of all time, with unique natural scenery and preserved rather than exploited for a moment. (3) Scarcity: Conservation Forests that stretch along the Park are the things that are rare in this era, and the concept of conservation or nature must continue to attract all time. (4) Optimization of Land Use: With land ownership that is so narrow, it will be possible for the agricultural sector and also to combine products with the development of agro-tourism. (5) Multiplication of Labor has a narrow land, while workers who are supposed to be ready to work continue to grow, so it is thought that that workers do not ready to work is not utilized or not channeled.

\section{Acknowledgements.}

This research supported byThe Ministry of Research and Higher Education of the Republic of Indonesia, through the Fundamental Research Grant for the fiscal year 2019-2020 and Dhyana Pura University, who have giving the opportunity to conduct research. We would likealso to thank to our research helper who gathered data on field survey.

\section{References}

[1] KSDA, „BKSDA Bali,“ 83 2019. [Online]. Available: https://www.ksda-bali.go.id/. [Cit. 83 2019].

[2] I Gusti Bagus Rai Utama, I Wayan Ruspendi Junaedi, Buku Agrowisata sebagai Pariwisata Alternatif Indonesia, 1 ed., Yogyakarta: Penerbit Buku Deepublish Yogyakarta CV. BUDI UTAMA, 2015.

[3] I. G. B. R. Utama, Statistik Penelitian Bisnis Dan Pariwisata, Dilengkapi Studi Kasus Penelitian, 1 ed., Yogyakarta: Penerbit Andi, 2018.

[4] I Gusti Bagus Rai Utama, Ni Made Eka Mahadewi, Metodologi Penelitian Pariwisata Dan Perhotelan, 1 ed., Yogyakarta: Penerbit Andi, 2012.

[5] Y. Syamsu, „Penerapan Etika Perencanaan pada kawasan wisata, studi kasus di kawasan Agrowisata Salak Pondoh, Kabupaten Sleman, Daerah Istimewa Yogyakarta,“ Jurnal Ilmiah Kepariwisataan, zv. Vol 5. No. 3 Maret 2001, \%1. vyd.LP3M STP Tri Sakti, p. LP3M STP Tri Sakti, 2001.

[6] N. Sutjipta, „Agrowisata. Magester manajemen Agribisnis,“ Universitas Udayana, Denpasar, 2001.

[7] Pujaastawa, Panduan THK Awards and accreditation tahun 2000, 1 ed., Denpasar: Green paradise, 2005.

[8] Fandeli, Dasar Dasar Manajemen Kepariwisataan Alam, 1 ed., Jakarta: Liberty, 2011.

[9] A. Postma, An Approach for integrated development of quality tourism. In Flanagan, S., Ruddy, J., Andrews, N. (2002) Innovation tourism planning, 1 ed., Dublin: Dublin Institute of Technology: Sage, 2002.

[10] I. G. B. R. Utama, Pengantar Industri Pariwisata, 1 ed., Yogyakarta: Penerbit Buku Deepublish Yogyakarta CV. BUDI UTAMA, 2015. 